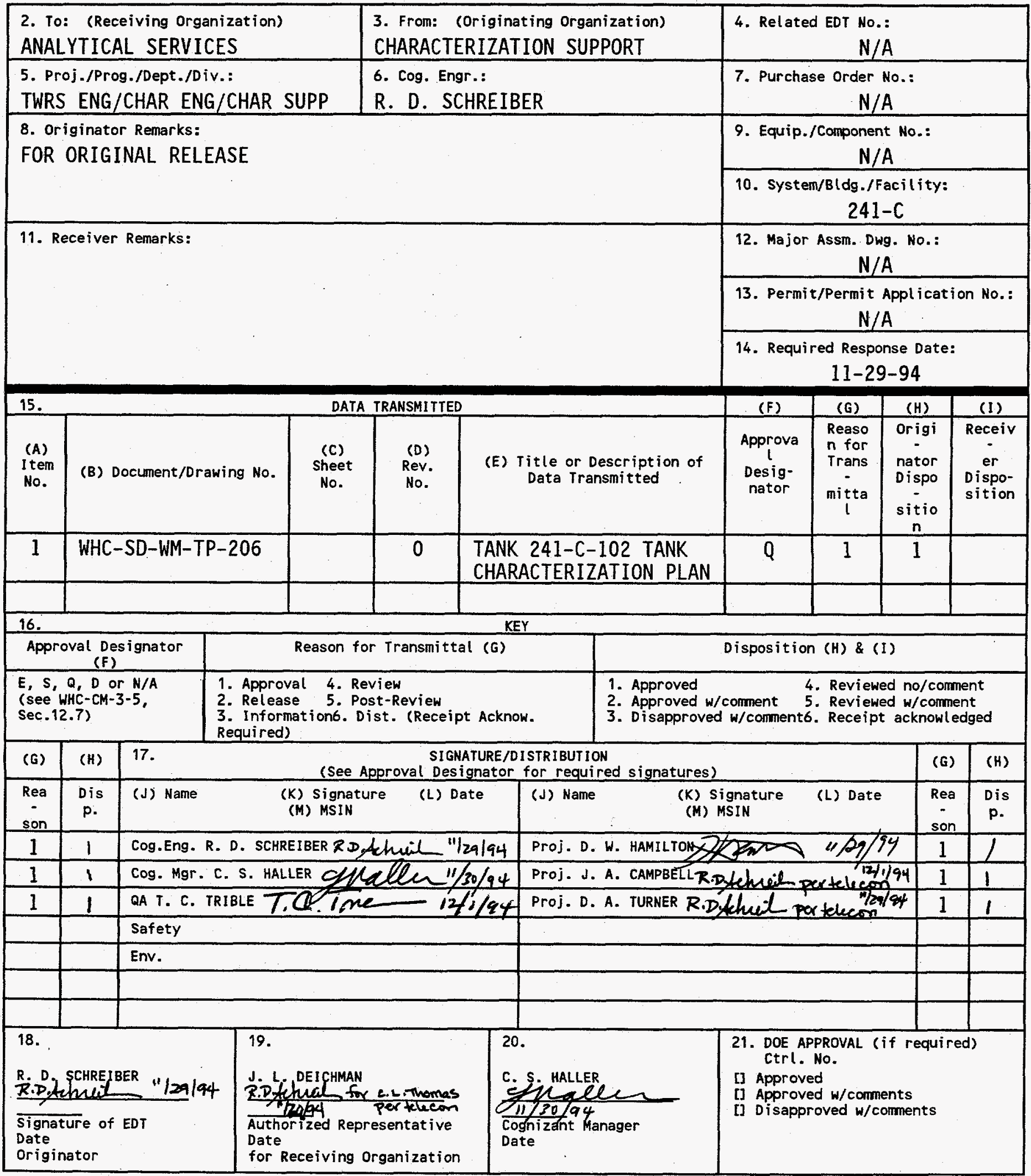

BD-7400-172-2 (04/94) GEF097 


\section{DISCLAIMER}

Portions of this document may be illegible in electronic image products. Images are produced from the best available original document. 


\section{SUPPORTING DOCUMENT}

1. Total Pages 13

2. Title

TANK 241-C-102 TANK CHARACTERIZATION PLAN

5. Key Words

CHARACTERIZATION, PROCESS DEVELOPMENT, QUALITY

CONTROL, SINGLE-SHELL TANK, SAMPLING, ANALYSIS,

TANK CHARACTERIZATION PLAN PPROVED FOR

3. Number

4. ReV No.

WHC-SD-WM-TP-206

0 $x_{m \beta} 12 / 1 / 94$ PUBLIC RELEASE

6. Author

Name: R. D. SCHREIBER

R.D.tehrial $1 / 29 / 94$

Organization/Charge Code

$71520 / N 4168$

7. Abstract

This document is a $\mathrm{plan}$ which serves as the contractual agreement between the Characterization Program, Sampling Operations, WHC 222-S Laboratory, and PNL 325 Analytical Chemistry Laboratory. The scope of this $\mathrm{plan}$ is to provide guidance for the sampling and analysis of samples from tank 241-c-102.

8.

RELEASE STAMP

OFFICIAL RELEASE

BY VHO

DATE

DEC 011994

STA4 


\section{RELEASE AUTHORIZATION}

\section{Document Number: WHC-SD-WM-TP-206, REV.0}

Document Title: $\quad$ TANK 241-C-102 TANK CHARACTERIZATION PLAN

Release Date: $\quad$ December 1, 1994

This document was reviewed following the procedures described in WHC-CM-3-4 and is:

\section{APPROVED FOR PUBLIC RELEASE}

WHC Information Release Administration Specialist:

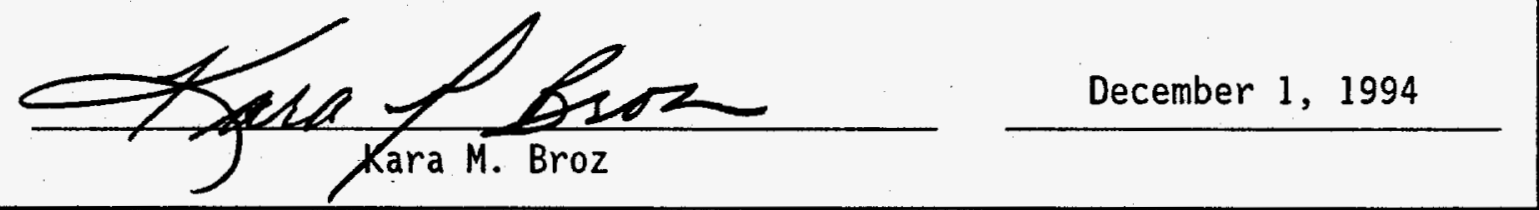

TRADEMARK DISCLAIMER. Reference herein to any specific commercial product, process, or service by trade name, trademark, manufacturer, or otherwise, does not necessarily constitute or imply its endorsement, recommendation, or favoring by the United states Government or any agency thereof or its contractors or subcontractors.

This report has been reproduced from the best available copy. Available in paper copy and microfiche. Printed in the United States of America. Available to the U.S. Department of Energy and its contractors from:

U.S. Department of Energy

office of Scientific and Technical Information (OSTI)

P.0. Box 62

Oak Ridge, TN 37831

Telephone: (615) $576-8401$

Available to the public from:

U.S. Department of Cormerce

National Technical Information Service (NTIS)

5285 Port Royal Road

Springfield, VA 22161

Telephone: (703) 487-4650 
WHC-SD-WM-TP-206

Revision 0

\title{
Tank 241-C-102 Tank Characterization Plan
}

\author{
Prepared for the U.S. Department of Energy \\ Office of Environmental Restoration \\ and Waste Management
}

\section{DISCLAIMER}

\begin{abstract}
This report was prepared as an account of work sponsored by an agency of the United States Government. Neither the United States Government nor any agency thereof, nor any of their employees, makes any warranty, express or implied, or assumes any legal liability or responsibility for the accuracy, completeness, or usefulness of any information, apparatus, product, or process disclosed, or represents that its use would not infringe privately owned rights. Reference herein to any specific commercial product, process, or service by trade name, trademark, manufacturer, or otherwise does not necessarily constitute or imply its endorsement, recommendation, or favoring by the United States Government or any agency thereof. The views and opinions of authors expressed herein do not necessarily state or reflect those of the United States Government or any agency thereof.
\end{abstract}


WHC-SD-WM-TP-206, REV. 0

CONTENTS

1.0 INTRODUCTION . . . . . . . . . . . . . . . . . . . . . 1

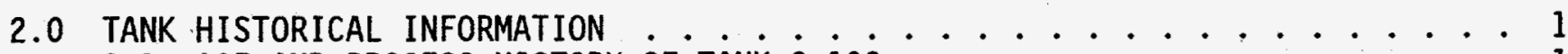
2.1 AGE AND PROCESS HISTORY OF TANK C-102 . . . . . . . . . . . . . . . . . 1

2.2 EXPECTED TANK CONTENTS ..................... 3

REFERENCES .............................. 3

\section{LIST OF TABLES}

Table 1 Waste Status Summary for Tank C-102 . . . . . . . . . . . . 2

Table 2 Historical Waste Constituents of Tank C-102 . . . . . . . . . . 3

\section{LIST OF FIGURES}

Figure 1 Tank C-102 Fill History . . . . . . . . . . . . . . . . 2

\section{LIST OF ABBREVIATIONS}

C-102 tank 241-C-102

CC complexant concentrate waste

DQO data quality objective

DST double-shell tank

OSD operational safety design

QA quality assurance

SST single-shell tank

TWRS Tank Waste Remediation System

WHC Westinghouse Hanford Company 


\subsection{INTRODUCTION}

The Defense Nuclear Facilities Safety Board has advised the DOE to concentrate the near-term sampling and analysis activities on identification and resolution of safety issues (Conway 1993). The data quality objective (DQO) process was chosen as a tool to be used to identify the sampling and analytical needs for the resolution of safety issues. As a result, a revision in the Federal Facility Agreement and Consent Order (Tri-Party Agreement) milestone M-44-00 has been made, which states that "A Tank Characterization Plan (TCP) will also be developed for each double shell tank (DST) and Single-shell tank (SST) using the DQO process... Development of TCPs by the DQO process is intended to allow users (e.g., Hanford Facility user groups, regulators) to ensure their needs will be met and that resources are devoted to gaining only necessary information." This document

satisfies that requirement for the tank 241-C-102 (C-102) fiscal year 1995 sampling activity.

\subsection{TANK, WASTE, AND SAMPLING INFORMATION}

This section summarizes some of the available information for tank $c-102$. Discussions of the process history, recent sampling events for the tank, and general information about the tank are included.

\subsection{AGE AND PROCESS HISTORY OF TANK C-102}

241-C Tank Farm was constructed between 1943 and 1944. The tanks were constructed with ASTM A283 Grade C Steel Liners. There are four 200-series 55,000 gallon, 20-ft diameter single shell tanks (SSTs). In addition, there are twelve 100series, 530,000 gallon, 75-ft diameter SSTs (Anderson 1992). Built as one of the first generation tank farms, the $C$ Tank Farm was designed for non-boiling waste with a maximum fluid temperature of $220^{\circ} \mathrm{F}$. The cascade overflow lines connect three tanks together. All twelve 530,000 gallon and all four 55,000 gallon tanks in the $C$ Tank Farm are out of service. As of July 1993, nine are categorized sound and seven are assumed leakers. Six tanks in the C Tank Farm are identified on a watch list.

Tank C-102 is a 530,000 gallon SST in the 241-C Tank Farm. It has been declared sound and has been partially interim isolated. This tank is classified as nonstabilized. C-102 currently contains dilute complexed waste (DC) with a total waste volume of $423,000 \mathrm{gal}$ (149 inches). All of the waste is sludge with $37,000 \mathrm{gal}$ of drainable interstitial liquid. There is no supernatant liquid. Dilute complexed waste is characterized by a high content of organic carbon including organic complexants: ethylenediaminetetra-acetic acid (EDTA), citric acid, and hydroxyethylethylenediaminetriacetic acid (HEDTA), being the major complexants used.

The 1ast solids update was 28-Apr-82 and the last photo taken was 18-May-76 (Hanton 1994). It shows a black sludge with small pockets of 1iquid. Figure 1 and Table 1 depict the fill history of $C-102$ since it began filling in May 1946. 
WHC-SD-WM-TP-206, REV. 0

Figure 1: Tank C-102 Fill History

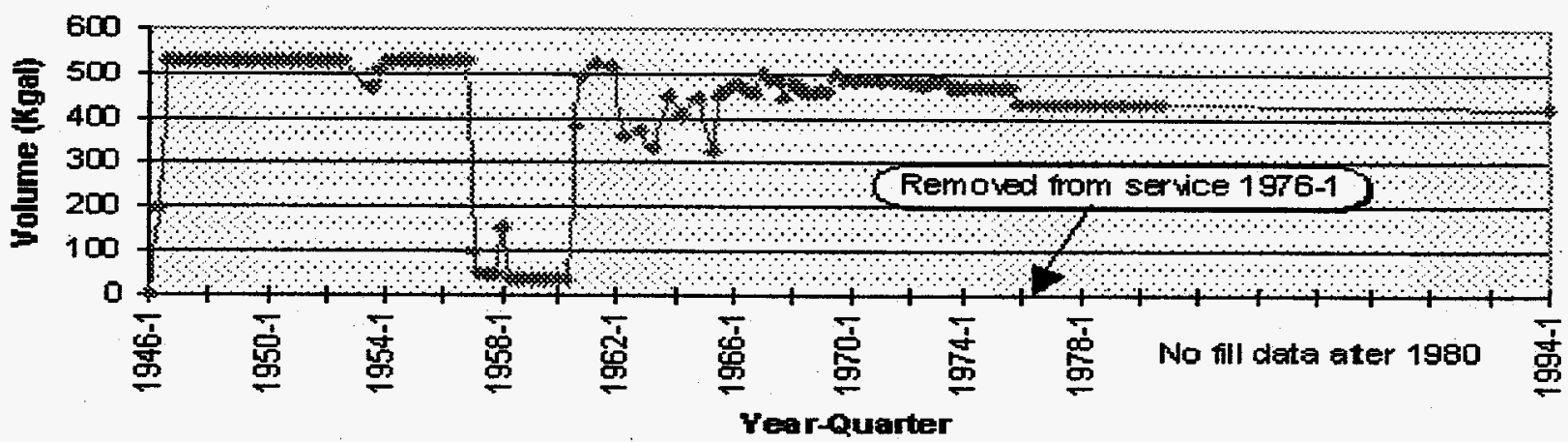

Table 1: Waste Status Summary for Tank C-102

\begin{tabular}{|c|c|c|c|c|c|c|c|c|c|c|}
\hline 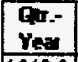 & $\begin{array}{l}\text { Tise } \\
\text { yaste }\end{array}$ & $\begin{array}{l}\text { Total } \\
\text { Yd. }\end{array}$ & $\begin{array}{l}\text { Liquid in } \\
\text { Storare }\end{array}$ & $\begin{array}{l}\text { Sadids in } \\
\text { Staregs }\end{array}$ & $\begin{array}{l}\text { Pocid } \\
\text { from: }\end{array}$ & $\begin{array}{l}\text { Val } \\
\text { recid: }\end{array}$ & $\begin{array}{l}\text { Moned } \\
\text { lax. }\end{array}$ & \begin{tabular}{|c|} 
Yal \\
moved:
\end{tabular} & $\begin{array}{l}\text { Geonth } \\
\text { repori }\end{array}$ & Pemurts \\
\hline $\begin{array}{l}1946-2 \\
1946-3 \\
1946-4\end{array}$ & $M$ & $\begin{array}{l}195 \\
528 \\
528\end{array}$ & $\begin{array}{l}- \\
- \\
-\end{array}$ & 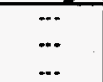 & & & & & & $\begin{array}{l}\text { Cascade, began firing h My } 1946 \\
\text { Fled in August } 1948 \\
\text { Cascade ful in Dotobel } 1946\end{array}$ \\
\hline $1952-4$ & $\mathrm{MW}^{\prime}$ & & 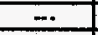 & $\cdots$ & & & & & & 984 in Casoade proc. fo feed to TP plant \\
\hline \begin{tabular}{|l|}
$1953-1$ \\
$1953-2$
\end{tabular} & $\begin{array}{l}M \\
M\end{array}$ & & $\ddot{m}$ & $\cdots$ & & . & CR1218 & 1651 & & $\begin{array}{l}1507 \text { in } 101 \text { hr u } 106-\mathrm{C} \\
\text { Smoll shudge heet }\end{array}$ \\
\hline 1953-3 & TEP & 467 & - & $\cdots$ & & & & & & Feceived TEPW aspe \\
\hline $1953-4$ & TEP & 508 & - & $\ldots$ & & & & & & Feceived TEP aste \\
\hline $\begin{array}{l}1957-1 \\
1957-2 \\
1957-3\end{array}$ & $\begin{array}{l}\text { TEP } \\
\text { OWW } \\
\text { TEP }\end{array}$ & $\begin{array}{l}98 \\
48 \\
48\end{array}$ & $\begin{array}{l}- \\
\cdots\end{array}$ & $\begin{array}{l}\cdots \\
\cdots \\
\cdots\end{array}$ & & & & & & $\begin{array}{l}\text { Latest electrode re ading } \\
\text { Soavenged during month }\end{array}$ \\
\hline $1957-4$ & TEP & 48 & $\cdots$ & $\ldots$ & & & & & & \\
\hline $\begin{array}{l}1958-1 \\
1958-2 \\
\end{array}$ & $\begin{array}{l}\text { TEP } \\
\operatorname{TBP}\end{array}$ & $\begin{array}{c}150 \\
37 \\
\end{array}$ & $\begin{array}{l}52 \\
37 \\
\end{array}$ & 98 & & & & & & $\begin{array}{l}\text { Lawest electrode reading } \\
\text { Liwest electrode reading }\end{array}$ \\
\hline 1959-3 & TEP & 34 & 34 & $\cdots$ & & & & & & Lavest electrode reading \\
\hline $1960-3$ & IEROW & 378 & $34-344$ & $\cdots$ & & 344 & & & & SS. CW \& Dlubion Rec'd \\
\hline $1960-4$ & TEPOW & 491 & $34-457$ & $\ldots$ & & $1+0$ & & & & previous resdings were incon tat \\
\hline $\begin{array}{l}1961-2 \\
1961-4\end{array}$ & $\begin{array}{l}\text { TEPOW } \\
\text { TEPOW }\end{array}$ & $\begin{array}{l}521 \\
519 \\
\end{array}$ & $\begin{array}{l}34-487 \\
34-485 \\
\end{array}$ & $\cdots$ & & & & & $\begin{array}{l}x \\
x \\
\end{array}$ & \\
\hline $\begin{array}{l}1962-2 \\
1962-4 \\
\end{array}$ & CW & $\begin{array}{l}356 \\
370 \\
\end{array}$ & $\begin{array}{l}356 \\
370 \\
\end{array}$ & $\ldots$ & & 986 & $B$ & 1142 & $\begin{array}{l}x \\
x\end{array}$ & \\
\hline $\begin{array}{l}1963-2 \\
1963-4 \\
\end{array}$ & CW & $\begin{array}{l}334 \\
450 \\
\end{array}$ & $\begin{array}{l}334 \\
450 \\
\end{array}$ & $\cdots$ & & $\begin{array}{l}829 \\
854 \\
\end{array}$ & & & $\begin{array}{l}\bar{x} \\
x \\
\end{array}$ & $\begin{array}{l}\text { Foe'd CW } \\
\text { Feced CW }\end{array}$ \\
\hline $\begin{array}{l}1964-2 \\
1964-4\end{array}$ & CW & $\begin{array}{l}407 \\
442 \\
\end{array}$ & $\begin{array}{l}40 ? \\
442 \\
\end{array}$ & 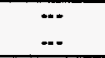 & A.202 & $\begin{array}{r}881 \\
1065 \\
\end{array}$ & & 1030 & & Fec'd DW \\
\hline $1965-2$ & CW & 326 & 88 & 238 & C108 & 1256 & & & & Feo'd. CW \\
\hline $\begin{array}{l}1965-3 \\
1965-4\end{array}$ & CW & $\begin{array}{l}447 \\
461 \\
\end{array}$ & $\begin{array}{l}209 \\
223 \\
\end{array}$ & $\begin{array}{l}238 \\
238 \\
\end{array}$ & & $\begin{array}{r}350 \\
278 \\
\end{array}$ & $\begin{array}{l}\mathrm{BY} * \mathrm{~T} \\
\mathrm{BY}-112 \\
\end{array}$ & $\begin{array}{l}232 \\
264 \\
\end{array}$ & & \\
\hline $\begin{array}{l}1966-1 \\
1966-2 \\
1966-3\end{array}$ & $\begin{array}{l}\text { CW } \\
\text { CW }\end{array}$ & $\begin{array}{l}472 \\
472 \\
464\end{array}$ & $\begin{array}{l}234 \\
234 \\
226\end{array}$ & $\begin{array}{l}238 \\
238 \\
238\end{array}$ & C108 & $\begin{array}{l}429 \\
556 \\
282\end{array}$ & $\begin{array}{l}\text { BY-112 } \\
\text { BY-111 } \\
\text { BY }\end{array}$ & $\begin{array}{l}418 \\
556 \\
290\end{array}$ & & $\begin{array}{l}\text { Alecd DW } \\
\text { Recid OW }\end{array}$ \\
\hline $1966-4$ & $\mathrm{CW}$ & 453 & 215 & 238 & & 44 & $B Y$ & 474 & & Pecid Cw \\
\hline $1967-1$ & OW & 499 & 261 & $\begin{array}{l}238 \\
238\end{array}$ & & $\begin{array}{l}370 \\
38 ?\end{array}$ & $\begin{array}{l}\text { BY: } \\
B Y \& T\end{array}$ & $\begin{array}{l}324 \\
400\end{array}$ & & \\
\hline $\begin{array}{l}1567-2 \\
1567-3 \\
1587-4\end{array}$ & $\begin{array}{l}\text { CW } \\
\text { CW } \\
\text { CW }\end{array}$ & $\begin{array}{l}486 \\
486 \\
444\end{array}$ & $\begin{array}{l}248 \\
248 \\
206\end{array}$ & $\begin{array}{l}238 \\
238 \\
238\end{array}$ & & $\begin{array}{l}387 \\
513 \\
362\end{array}$ & $\begin{array}{l}B Y+T \\
B Y \\
B Y\end{array}$ & $\begin{array}{l}713 \\
404\end{array}$ & & $\begin{array}{l}\text { Fecid FFEXCW } \\
\text { Pred FFEX }\end{array}$ \\
\hline \begin{tabular}{|l|}
$1568-1$ \\
$1968-2$ \\
$1568-3$ \\
$1968-4$ \\
\end{tabular} & $\begin{array}{l}\text { CW } \\
\text { CW-OWW } \\
\text { CW-OWW } \\
\text { CW-OWW }\end{array}$ & $\begin{array}{l}476 \\
466 \\
455 \\
457 \\
\end{array}$ & $\begin{array}{c}238 \\
28.200 \\
147-70 \\
89-61 \\
\end{array}$ & $\begin{array}{l}238 \\
238 \\
238 \\
307 \\
\end{array}$ & & $\begin{array}{l}735 \\
559 \\
786 \\
885 \\
\end{array}$ & $\begin{array}{c}E \times 100,105 \\
B \times 100 \\
B \times 100 \\
\end{array}$ & $\begin{array}{l}599 \\
765 \\
883 \\
\end{array}$ & & 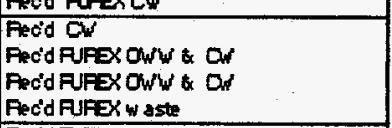 \\
\hline $1989-1$ & CW-OWW & 462 & $52-78$ & 332 & & 483 & EXI03 & 478 & & Fic'dPUFEX w ast \\
\hline $1969-2$ & DW-OWW & 458 & 52.37 & 369 & & 872 & & & & Fec'd PUFEX w aste \\
\hline $1969-3$ & DW-OWH & 501 & 41.109 & 351 & & 7800 & $E \geqslant 100$ & 738 & & Fec'd AUFEX w aste \\
\hline $1959-4$ & DW-OWW & 486 & $42-99$ & 345 & $C_{108}$ & 925 & Ex-100 & 94 & & Fec'd FuFEXw aste \\
\hline $1975-4$ & OW.ONWW & 431 & 25.74 & 332 & & & $\mathrm{C} 103$ & 111 & & \\
\hline $\begin{array}{l}1976-1 \\
1976-2 \\
\end{array}$ & $\begin{array}{c}\text { CW-OWW } \\
-:\end{array}$ & $\begin{array}{l}431 \\
431 \\
\end{array}$ & $\begin{array}{r}30 \\
0 \\
\end{array}$ & $\begin{array}{r}62 \\
431 \\
\end{array}$ & & & & & & $\begin{array}{l}\text { Fertoded fi serwioe } \\
\text { Ferroved if service }\end{array}$ \\
\hline $\begin{array}{l}1977-2 \\
1977-3\end{array}$ & $\ddot{m}$ & $\begin{array}{l}431 \\
431\end{array}$ & $\begin{array}{l}0 \\
0\end{array}$ & $\begin{array}{l}431 \\
431\end{array}$ & & & & & & $\begin{array}{l}\text { Sat Well Rumped } \\
\text { Sat Well Rumped }\end{array}$ \\
\hline $1977-4$ & $=$ & 431 & 0 & 431 & & & & & & Insetive Ourrert Saltwell Installed \\
\hline 1978-1 & - & 431 & 0 & 431 & & & & & & Insctive \\
\hline $1994-1$ & $\overline{D C}$ & $\$ 23$ & & & & & & & & 37 interstitid hquid 0 supernste \\
\hline
\end{tabular}




\subsection{EXPECTED TANK CONTENTS}

Samples of the supernate from tank $C-102$ were collected in 1991 , and analyses were performed. A summary of the information resulting from this characterization effort can be found in Table 2 .

Table 2: Historical Waste Constituents of Tank $\mathrm{C}-102^{\mathrm{C}}$

\begin{tabular}{|c|c|c|c|c|c|}
\hline Analyte & \multicolumn{2}{|c|}{ Result } & Analyte & \multicolumn{2}{|c|}{ Result } \\
\hline A1 & 2,800 & $\mu \mathrm{g} / \mathrm{g}$ & $\mathrm{Sn}$ & 63 & $\mu \mathrm{g} / \mathrm{g}$ \\
\hline As & 2.00 & $\mu \mathrm{g} / \mathrm{g}$ & $\mathrm{CN}$ & 79 & $\mu \mathrm{g} / \mathrm{g}$ \\
\hline $\mathrm{Ca}$ & 1.51 & $\mu \mathrm{g} / \mathrm{g}$ & $\mathrm{CO}_{3}$ & 18,000 & $\mu \mathrm{g} / \mathrm{g}$ \\
\hline $\mathrm{Cr}$ & 48 & $\mu \mathrm{g} / \mathrm{g}$ & $\mathrm{NO}_{2}$ & 16,000 & $\mu \mathrm{g} / \mathrm{g}$ \\
\hline $\mathrm{Fe}$ & 29 & $\mu \mathrm{g} / \mathrm{g}$ & $\mathrm{NO}_{3}$ & 31,000 & $\mu \mathrm{g} / \mathrm{g}$ \\
\hline$K$ & 760 & $\mu \mathrm{g} / \mathrm{g}$ & $\mathrm{SO}_{4}$ & 650 & $\mu \mathrm{g} / \mathrm{g}$ \\
\hline $\mathrm{Mg}$ & 4.5 & $\mu \mathrm{g} / \mathrm{g}$ & TOC & 2,800 & $\mu \mathrm{g} / \mathrm{g}$ \\
\hline$M n$ & 0.30 & $\mu \mathrm{g} / \mathrm{g}$ & ${ }^{60} \mathrm{Co}$ & 0.13 & $\mu \mathrm{Ci} / \mathrm{g}$ \\
\hline Mo & 3.8 & $\mu \mathrm{g} / \mathrm{g}$ & ${ }^{137} \mathrm{Cs}$ & 14 & $\mu \mathrm{Ci} / \mathrm{g}$ \\
\hline $\mathrm{Na}$ & 54,000 & $\mu \mathrm{g} / \mathrm{g}$ & ${ }^{239 / 240} \mathrm{Pu}$ & 0.0051 & $\mu \mathrm{Ci} / \mathrm{g}$ \\
\hline $\mathrm{Se}$ & 0.035 & $\mu \mathrm{g} / \mathrm{g}$ & ${ }^{89 / 90} \mathrm{Sr}$ & 0.016 & $\mu \mathrm{Ci} / \mathrm{g}$ \\
\hline $\mathrm{Si}$ & 23 & $\mu \mathrm{g} / \mathrm{g}$ & ${ }^{99} \mathrm{TC}$ & 0.014 & $\mu \mathrm{Ci} / \mathrm{g}$ \\
\hline
\end{tabular}

${ }^{c}$ (Edrington 1991)

\section{REFERENCES}

Anderson, J. D., 1992, A History of the 200 Area Tank Farms, WHC-MR-0132, Westinghouse Hanford Company, Richland, Washington.

Conway, J. T., Letter to H. R. O'Leary, DOE, "DNFSB Recommendation 93-5 to the Secretary of Energy," 9400070, dated July 19, 1993.

Edrington, R. S., June 3, 1991, BY and C Tank Farm Supernate Sample Analyses (Revision of 16220-PCL90-117), Internal letter 28110-PCL91-048, Westinghouse Hanford Company, Richland, Washington.

Hanion, B. M., 1994, Tank Farm Surveillance and Waste Status Summary Report for March 1994, WHC-EP-0182-72, Westinghouse Hanford Company, Richland, Washington.

ICF Kaiser Hanford Company, 1994. Historical Tank Content Estimate for the Northeast Quadrant of the Hanford 200 East Areas, WHC-EP-0759, Rev. 0, Westinghouse Hanford Company, Richland, Washington. 
WHC-SD-WM-TP-206, REV. 0

APPENDIX A

SAMPLING AND ANALYSIS PLAN FOR AUGER SAMPLING IN FISCAL YEAR 1995

A-1 
WHC-SD-WM-TP-206, REV. 0

This page intentionally left blank. 
WHC-SD-WM-TP-206, REV. 0

\section{CONTENTS}

SAMPLING AND ANALYSIS PLAN FOR AUGER SAMPLING IN FISCAL YEAR 1995

1.0 SPECIFIC TANK OBJECTIVE ....................... A-4

1.1 RELEVANT SAFETY ISSUES . . . . . . . . . . . . . . . . . . . . . A-4

1.1.1 C-102 Characterization Objectives . . . . . . . . . . . . A-4

1.1.2 Applicable Data Quality Objectives . . . . . . . . . . . A-5

2.0 SAMPLING INFORMATION . . . . . . . . . . . . . . . . A-5

2.1 SAMPLE COLLECTION . . . . . . . . . . . . . . . . . A-5

2.2 SAMPLE CUSTODY . . . . . . . . . . . . . . . . . . . A-5

3.0 LABORATORY INSTRUCTIONS . . . . . . . . . . . . . . . . . A-6

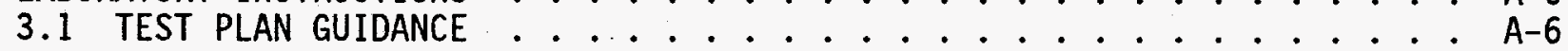

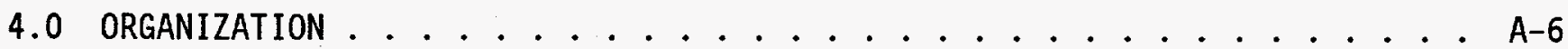

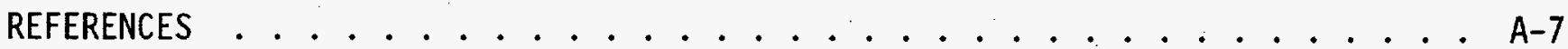

\section{LIST OF TABLES}

Table 1 Tank C-102 Project Key Personnel List . . . . . . . . . . . A-7

\section{LIST OF ABBREVIATIONS}

C-102 241-C-102

C-103 241-C-103

DQO data quality objective 
WHC-SD-WM-TP-206, REV. 0

\subsection{SPECIFIC TANK OBJECTIVES}

Tank 241-C-102 (C-102) is to be sampled for process development purposes. Since process development data needs are rarely ever defined such that they can be incorporated into a Data Quality Objectives effort, a test plan (Campbell 1994) has been written to administer analytical guidance to the 222-S Laboratory for this sampling event. This Tank Characterization Plan will reference that test plan, and is focused on providing guidance to Sampling Operations personnel.

\subsection{RELEVANT SAFETY ISSUES}

Large quantities of organic solvents (mostly TBP and NPH) have been disposed to single-shel1 underground storage tanks (SSTs) from various Hanford Site chemical processing facilities. When disposed to the SSTs, it is anticipated that the organic solvent formed a separate (floating) organic layer on the aqueous supernate since the density of the organic solvent is less than that of the aqueous supernate (less than $1.0 \mathrm{~g} / \mathrm{mL}$ versus approximately $1.37 \mathrm{~g} / \mathrm{mL}$ ).

Many of the SSTs have been or are in the process of being interim stabilized, where the free aqueous supernate is removed by pumping from the bottom of the tanks. As the interim stabilization pumping occurs, any organic solvent present eventually contacts the solid waste surface and has an opportunity to permeate into the waste solids. Since the porosities of the waste solids typically range from about $20 \%$ to $60 \%$ of the bulk volume, the organic solvent could occupy a significant fraction of the waste solids pure space.

The safety concern which arises from this possible scenario could be stated as follows:

- Does entrainment of organic solvents in waste solids constitute a flammability hazard?

Unfortunately, the phenomenology of organic solvents permeating waste solids, and thereby constituting a potential flammability hazard, is not adequately understood and therefore must be investigated through waste simulant studies. These waste simulant studies will focus on determining if organic solvent permeates into waste solvents during interim stabilization, and will assess the conditions required to support combustion. Of particular emphas is will be the determination of whether a localized combustion event could spread into a larger deflagration.

To satisfactorily understand the phenemenology in question, the physical properties of the simulant must bound the relevant physical properties of actual tank waste. In order to produce a simulant, therefore, waste samples from selected tanks known to contain, or to formerly have contained, separate (floating) organic solvent are being requested.

\subsubsection{C-102 Characterization Objectives}

Tank 241-C-102 (C-102) formerly contained a separate (floating) organic layer. As well, a portion of the waste material in tank $\mathrm{C}-102$ was pumped to tank $\mathrm{C}-103$. Tank C-102 was subsequently interim stabilized, presumably with some quantity of organic solvent floating on the aqueous supernate during the pumping operations. Therefore, in order to determine if organic solvent is entrained in waste solids during interim 
WHC-SD-WM-TP-206, REV. 0

stabilization, auger samples from the surface of the waste in tank C-102 shall be retrieved and analyzed per (Campbell 1994).

\subsubsection{Applicable Data Quality Objectives}

Current7y, there are no applicable Data Quality Objectives (DQOs) for this specific sampling event. Since this sampling event is for process development purposes only, no safety screening will be performed on the waste (this will be performed when the tank is rotary-mode core sampled). In lieu of a DQO, a test plan (Campbel1 1994) shall be used.

\subsection{SAMPLING INFORMATION}

\subsection{SAMPLE COLLECTION}

A total of two auger samples are to be taken, from risers 3 and 6 , using the nine inch auger. The auger samples are to be shipped to the 222-S Laboratory by Sampling Operations in accordance with work package ES-93-02194. That work package shal1 also initiate the chain-of-custody for the samples.

Samples shall be identified by a unique number before being shipped to the 222-S Laboratory. The sampling team is responsible for documenting any problems and procedural changes affecting the validity of the sample in a field notebook. Sampling Operations shall enter this information in the comment section of the chain-of-custody form for addition to the data reports.

For this sampling event, no field blank shall be taken. The $C-102$ samples to be taken during this activity are not for any RCRA regulatory purposes. Therefore, no field blank is necessary (Zuroff 1994).

Sampling Operations should send the auger samples to the laboratory within one business day of removing each sample from tank $\mathrm{C}-102$, but must send each sample within three calendar days. Sampling Operations is responsible for verbally notifying the shift manager at the laboratory (373-2435) at least 24 hours in advance of an expected shipment. If samples are going to be delivered after 3:00 $\mathrm{pm}$, the laboratory shall be notified at least four hours in advance of actual sample shipment so that proper shift operations can be planned.

\subsection{SAMPLE CUSTODY}

The chain-of-custody form is initiated by the sampling team as described in the work package. Auger samples are shipped in a cask and sealed with a Waste Tank Sample Seal. Al1 sample shipments are to be labeled with the following information:

WASTE TANK SAMPLE SEAL

Supervisor

Date of Sampling

Shipment No.
Sample No.

Time of Sampling

Serial No. 


\section{WHC-SD-WM-TP-206, REV. 0}

The sealed and labeled samples are shipped to the laboratory along with the chain-of-custody form, which identifies the tank and riser information. The receipt and control of samples in the Westinghouse Hanford 222-S Laboratory is described in procedure 10-090-101.

\subsection{LABORATORY INSTRUCTIONS}

\subsection{TEST PLAN GUIDANCE}

Analytical guidance for this process development effort will be administered through a test plan. "Analytical Plan for Single-She11 Tank Waste Samples: 241-C-102, 241-C-103, and 241-BY-108" (Campbe17 1994) explains the testing to be performed on the auger samples from tank $C-102$. This test $p l a n$ explains in detail the experiments to be run on the waste from the tank, and also includes information regarding quality assurance and scheduling.

Since the Characterization Program is responsible for the taking of tank samples, the Characterization Program and TWRS Programs Quality Assurance will need to approve the test plan. This approval will not only ensure that the DQO process has been used in the generation of the test plan and that there is justification for the samples, but also that the facility receiving the sample is in a position to adequately handle radioactive material. At such time that the test $p$ lan is approved, the Characterization Program will direct either the shipment of the sample material or, if it is already in the possession of the performing laboratory, the start of analytical work.

It should be noted that in accordance with the Safety and Analys is Report for Packaging (SARP), auger samples from tank $\mathrm{C}-102$ must be vented every 15 days from the time of the cask sealing to allow any retained gas to escape.

\subsection{ORGANIZATION}

The organization and responsibility of key personnel involved in this tank C-102 characterization project are listed in Table 1. 
WHC-SD-WM-TP-206, REV. 0

Table 1: Tank C-102 Project Key Personnel List.

\begin{tabular}{||c|c|c|}
\hline Individual & Organization & Responsibility \\
\hline K. B. Wehner & $\begin{array}{c}\text { WHC 222-S Process } \\
\text { Chemistry Laboratories }\end{array}$ & $\begin{array}{c}\text { Manager, Organic } \\
\text { Chemistry Group }\end{array}$ \\
\hline J. A. Campbe11 & $\begin{array}{c}\text { PNL 329 Laboratory, } \\
\text { Advanced Organic } \\
\text { Analytical Methods } \\
\text { Group }\end{array}$ & $\begin{array}{c}\text { PNL Point of Contact } \\
\text { for C-102 Process } \\
\text { Development work }\end{array}$ \\
\hline R. D. Schreiber & $\begin{array}{c}\text { TWRS Characterization } \\
\text { Support }\end{array}$ & $\begin{array}{c}\text { C-102 Tank } \\
\text { Characterization P1 an } \\
\text { Cognizant Engineer }\end{array}$ \\
\hline D. A. Turner & Organic Safety Program & $\begin{array}{c}\text { Manager, Organic Safety } \\
\text { Program }\end{array}$ \\
\hline J. L. Deichman & Analytical Services & $\begin{array}{c}\text { Manager, Program } \\
\text { Management and } \\
\text { Integration }\end{array}$ \\
\hline
\end{tabular}

\section{REFERENCES}

Campbel1, J. A., 1994, Analytical Plan for Single-Shell Tank Waste Samples: 241-C-102, 241-C-103, and 241-BY-108, draft, Pacific Northwest Laboratory, Richland, Washington.

Zuroff, W. F., 1994, Auger Trip Blanks, (cc:Mail to R.D. Schreiber, T. E. Whel an, and G. D. Johnson, February 10), Westinghouse Hanford Company, Richland, Washington. 